February 2005 • NREL/CP-520-37524

\title{
Direct Write Contacts for Solar Cells
}

T. Kaydanova, M.F.A.M. van Hest, A. Miedaner, C.J. Curtis, J.L. Alleman, M.S. Dabney, E. Garnett, S. Shaheen, and D. Ginley National Renewable Energy Laboratory

L. Smith and R. Collins

Colorado School of Mines

J.I. Hanoka and A.M. Gabor Evergreen Solar, Inc.

Prepared for the $31^{\text {st }}$ IEEE Photovoltaics Specialists Conference and Exhibition Lake Buena Vista, Florida January 3-7, 2005
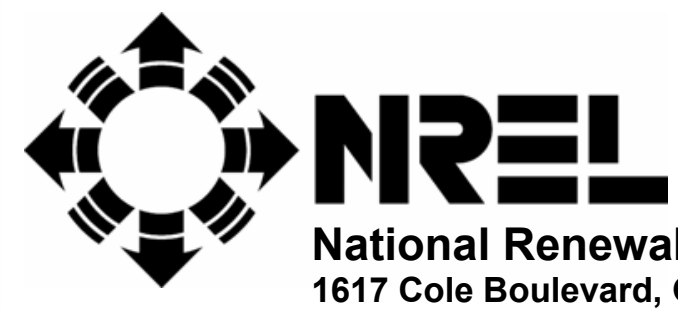

National Renewable Energy Laboratory 1617 Cole Boulevard, Golden, Colorado 80401-3393 303-275-3000 • www.nrel.gov

Operated for the U.S. Department of Energy Office of Energy Efficiency and Renewable Energy by Midwest Research Institute $\bullet$ Battelle 


\section{NOTICE}

The submitted manuscript has been offered by an employee of the Midwest Research Institute (MRI), a contractor of the US Government under Contract No. DE-AC36-99G010337. Accordingly, the US Government and MRI retain a nonexclusive royalty-free license to publish or reproduce the published form of this contribution, or allow others to do so, for US Government purposes.

This report was prepared as an account of work sponsored by an agency of the United States government. Neither the United States government nor any agency thereof, nor any of their employees, makes any warranty, express or implied, or assumes any legal liability or responsibility for the accuracy, completeness, or usefulness of any information, apparatus, product, or process disclosed, or represents that its use would not infringe privately owned rights. Reference herein to any specific commercial product, process, or service by trade name, trademark, manufacturer, or otherwise does not necessarily constitute or imply its endorsement, recommendation, or favoring by the United States government or any agency thereof. The views and opinions of authors expressed herein do not necessarily state or reflect those of the United States government or any agency thereof.

Available electronically at http://www.osti.gov/bridge

Available for a processing fee to U.S. Department of Energy and its contractors, in paper, from:

U.S. Department of Energy

Office of Scientific and Technical Information

P.O. Box 62

Oak Ridge, TN 37831-0062

phone: 865.576 .8401

fax: 865.576.5728

email: mailto:reports@adonis.osti.gov

Available for sale to the public, in paper, from:

U.S. Department of Commerce

National Technical Information Service

5285 Port Royal Road

Springfield, VA 22161

phone: 800.553 .6847

fax: 703.605.6900

email: orders@ntis.fedworld.gov

online ordering: http://www.ntis.gov/ordering.htm 


\title{
Direct Write Contacts for Solar Cells
}

\author{
Tanya Kaydanova ${ }^{1}$, Maikel F.A.M van Hest ${ }^{1}$, Alex Miedaner ${ }^{1}$, Calvin J. Curtis ${ }^{1}$, Jeff L. Alleman ${ }^{1}$, Matthew S \\ Dabney $^{1}$, Eric Garnett ${ }^{1}$, Sean Shaheen ${ }^{1}$,Lee Smith ${ }^{2}$, Reubin Collins ${ }^{2}$, Jack I. Hanoka ${ }^{3}$, Andrew M. Gabor ${ }^{3}$ \\ and David S. Ginley ${ }^{1}$ \\ ${ }^{1}$ National Renewable Energy Laboratory, 1617 Cole Blvd., Golden Colorado 80401 USA \\ ${ }^{2}$ Colorado School of Mines, Golden Colorado 80401 USA, \\ ${ }^{3}$ Evergreen Solar, Inc., 259 Cedar Hill Street, Marlboro, MA 01752 USA
}

\begin{abstract}
$\mathrm{Ag}, \mathrm{Cu}$ and Ni metallizations were inkjet printed with near vacuum deposition quality. The approach developed can be easily extended to other conductors such as $\mathrm{Pt}$, $\mathrm{Pd}, \mathrm{Au}$ etc. Thick highly conducting lines of $\mathrm{Ag}$ and $\mathrm{Cu}$ demonstrating good adhesion to glass, $\mathrm{Si}$ and $\mathrm{PCB}$ have been printed at $100-200^{\circ} \mathrm{C}$ in air and $\mathrm{N}_{2}$ respectively. Ag grids were inkjet-printed on $\mathrm{Si}$ solar cells and fired through the silicon nitride $\mathrm{AR}$ layer at $850^{\circ} \mathrm{C}$ resulting in $8 \%$ cells. Next generation multicomponent inks (including etching agents) have also been developed with improved fire through contacts leading to higher cell efficiencies. PEDOT-PSS polymer based conductors were inkjet printed with conductivity as good or better than that of spin-coated films.
\end{abstract}

\section{INTRODUCTION}

Inkjet printing is rapidly becoming a viable alternative to the existing deposition approaches for a variety of inorganic and organic electronic materials[1]. For metallizations with appropriate inks, it can replace vacuum deposition, screen printing and electroplating. The advantage of inkjet printing is that it is an atmospheric process capable of resolution higher than in screenprinting (features as small as $5 \mu \mathrm{m}$ have been produced using an inkjet). It is a non-contact, potentially 3D deposition approach, which makes it ideally suited to processing thin and fragile substrates. The composition of the inks may be easily tailored by the addition of elements such as adhesion promoters and doping compounds to optimize mechanical and electronic properties of the subsequently processed contact. In addition, inkjet printing is inherently suited for printing multilayer/multicomponent structures. We report here on ink-based approaches to printing $\mathrm{Ag}, \mathrm{Cu}$ and $\mathrm{Ni}$ metallizations with near vacuum deposition quality. This approach can by analogy be easily extended to other conductors such as $\mathrm{Pt}, \mathrm{Pd}$, Au etc.

\section{INKJET-PRINTED METALS}

Organometalic compounds of $\mathrm{Ag}, \mathrm{Cu}$ and $\mathrm{Ni}$ in organic solvents (proprietary compositions) were used as the precursor inks for inkjet and spray printing of the metallic layers and patterns. When spray-printed with an airbrush on heated glass substrates at $200-250^{\circ} \mathrm{C}$ in air, the metal precursor inks fully decomposed forming metallic coatings without detectable traces of carbon[2] or oxides (Fig. 1).

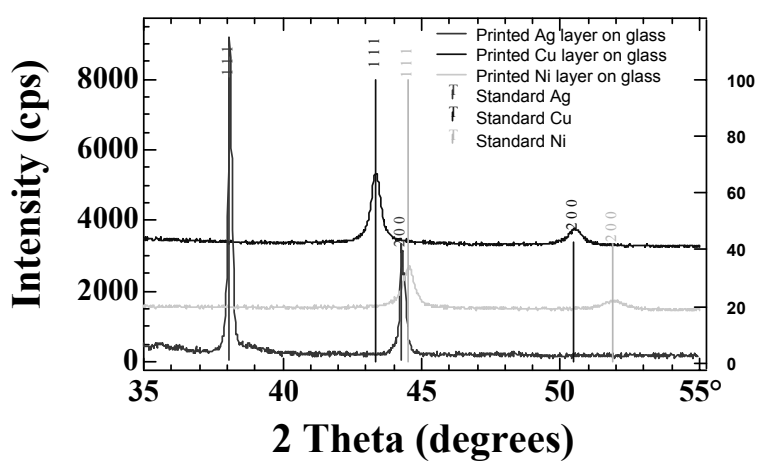

Fig 1. X-ray diffraction patterns of the spray-printed organometallic precursor inks.

The inkjet printer set up is pictured on Fig. 2. It consists of a stationary drop-on-demand piezoelectric inkjet head from Microfab Technologies with a 50-micron orifice. A resistive substrate heater plate positioned on an $X-Y$ stage directly under the inkjet serves to provide heating and $x-y$ positioning to $1 \mu \mathrm{m}$. Printing parameters such as substrate temperature and translation speed, as well as the inkjet driving parameters, the frequency and amplitude of the controlling voltage pulses, were optimized to achieve the best resolution and highest conductivity for $\mathrm{Ag}$ and $\mathrm{Cu}$ metals.

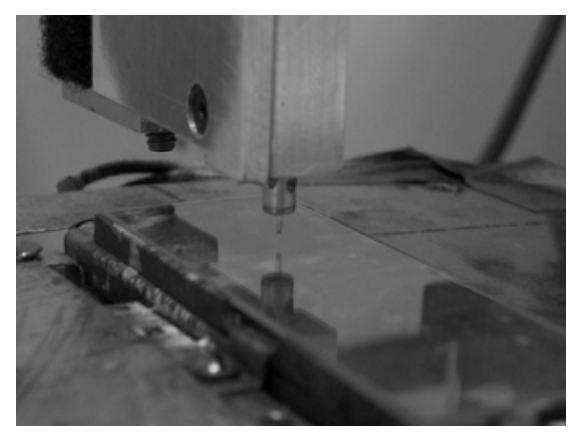

Fig. 2. Inkjet printhead positioned over a glass substrate.

Thick (up to $15 \mu \mathrm{m}$ ), highly conducting lines of $\mathrm{Ag}$ and $\mathrm{Cu}$ were printed on a variety of substrates, demonstrating good adhesion to glass, Si and PCB (Figure 3a,b). The inkjet parameters for Ni printing have not yet been optimized. 
In general we found that the best $\mathrm{Cu}$ deposits were obtained in an inert atmosphere ( $\mathrm{N}_{2}$ or $\mathrm{Ar}$ ). However, pure $\mathrm{Cu}$ coatings, including the one shown in Fig. 1, were obtained in air using rapid thermal processing.
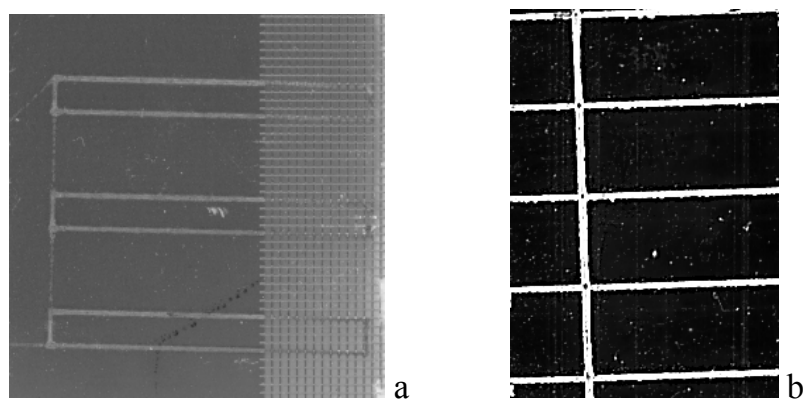

Fig 3. (a) $300 \mu \mathrm{m}$ wide, $5-\mu \mathrm{m}$ thick $\mathrm{Cu}$ lines printed on $\mathrm{PCB}$ in $\mathrm{N}_{2}$ at $200^{\circ} \mathrm{C}$. (b) $250 \mu \mathrm{m}$ wide, $10 \mu \mathrm{m}$ thick Ag grids inkjet-printed on a Si solar cell in air at $200^{\circ} \mathrm{C}$.

A summary of the important characteristics of the inkjetprinted contacts produced to date is presented in Table 1. Typical conductivities for the metallic coatings were: $2 \mu \mathrm{Ohm}^{*} \mathrm{~cm}$ for $\mathrm{Ag}, 10 \mu \mathrm{Ohm}^{*} \mathrm{~cm}$ for $\mathrm{Cu}$ and $100 \mu \mathrm{Ohm}{ }^{*} \mathrm{~cm}$ for $\mathrm{Ni}$. The conductivity of the Ag layer is essentially that of the bulk metal, the $\mathrm{Cu}$ and spray-printed Ni layers demonstrate approximately an order of magnitude higher resistivity than the bulk values. Improving conductivity of printed $\mathrm{Cu}$ and $\mathrm{Ni}$ metallizations is an area of active investigation.

Table1. Important Characteristics of Printed Conductor Patterns

\begin{tabular}{|l|l|l|l|l|}
\hline Material & $\begin{array}{l}\text { Thick } \\
\text { ness } \\
(\mu \mathrm{m})\end{array}$ & $\begin{array}{l}\text { Line- } \\
\text { width } \\
(\mu \mathrm{m})\end{array}$ & $\begin{array}{l}\text { Resistivity } \\
(\mu \quad . \mathrm{cm})\end{array}$ & $\begin{array}{l}\text { Printing } \\
\text { temperatur } \\
\mathrm{e}\left({ }^{\circ} \mathrm{C}\right)\end{array}$ \\
\hline $\mathrm{Ag}^{(1)}$ & $1-15$ & $\begin{array}{l}100- \\
250\end{array}$ & 2 & 200 \\
\hline $\mathrm{Ag}^{(2)}$ & $1-15$ & $\begin{array}{l}300- \\
600\end{array}$ & 7 & 250 \\
\hline $\mathrm{Cu}$ & $1-15$ & $\begin{array}{l}200- \\
300\end{array}$ & 10 & 250 \\
\hline $\mathrm{Ni}$ & 4 & 300 & 700 & 250 \\
\hline $\begin{array}{l}\text { PEDOT: } \\
\text { PSS }\end{array}$ & 0.1 & 100 & $50-75$ \\
\hline $\begin{array}{l}\text { Fire- } \\
\text { through } \\
\text { agent }\end{array}$ & $1-5$ & $\begin{array}{l}70- \\
200\end{array}$ & $\mathrm{NA}$ & 200 \\
\hline
\end{tabular}

(1) - Ag from metalorganic ink developed at NREL

(2) - Ag from frit-containing nanoparticle ink (Ferro)

\section{INKJET-PRINTED SILVER GRIDS ON CRYSTALLINE SILICON SOLAR CELLS}

\section{Pure Ag grids}

$250 \mu \mathrm{m}$ wide, $10 \mu \mathrm{m}$ thick Ag lines were inkjet-printed on silicon nitride coated Si ribbon $\mathrm{p} / \mathrm{n}$ junctions provided by Evergreen Solar, Inc. $1 \mu \mathrm{m}$ thick Al back contacts were deposited by e-beam evaporation. The two contacts were co-fired in a single annealing step at $850^{\circ} \mathrm{C}$ for $10 \mathrm{~min}$ in air, forming a solar cell with $8 \%$ efficiency, Voc $=0.529 \mathrm{~V}$, $\mathrm{Jsc}=22.67 \mathrm{~mA}$ and a fill factor of 0.65 (Figure $3 \mathrm{~b}$ ). In this experiment the ohmic contact between $\mathrm{Ag}$ and $\mathrm{Si}$ was formed through the SiNx layer without the use of glass frits. The high temperature and long time required for the penetration of the Ag through the AR coating [3]can be detrimental for the junction. Facilitating the process of burning through the AR coating is desirable to lower the temperature and time of annealing for the inkjet-printed contacts. In order to achieve this goal we explored two independent directions described below.

\section{Grids from glass containing silver inks.}

Glass-frit containing inks analogous to screen-printed pastes in composition but with nanosized Ag particles were supplied by Ferro. The small particle size of the Ag powders used in these inks make them suitable for inkjet printing with the $50 \mu \mathrm{m}$ jet. They were successfully printed resulting in $15 \mu \mathrm{m}$ thick, $500 \mu \mathrm{m}$ wide lines (Figure 4 ).

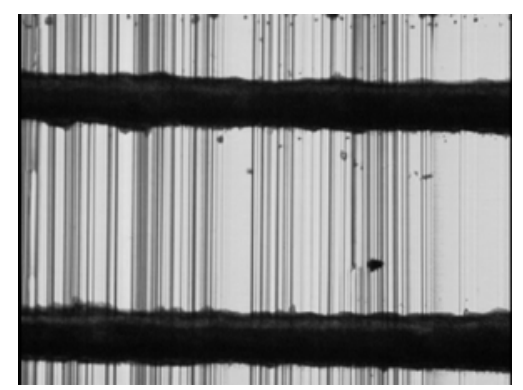

Fig. 4. 100x microscope image of the $15 \mu \mathrm{m}$ thick, $500 \mu \mathrm{m}$ wide Ag lines inkjet printed from Ferro's frit-containing ink

Using these inks, ohmic contacts were achieved at much lower temperatures $\left(650^{\circ} \mathrm{C}, 750^{\circ} \mathrm{C}\right)$ with a very short annealing cycle (less than a minute). Further optimization of the ink composition and printing processes is underway.

\section{Pure Ag grids with etching underlayer}

Simultaneously we explored another approach to reduced times and temperatures for processing inkjet-printed silver contacts. A significant advantage of inkjet printing is that it allows multi-layer printing so that separate writing of the contact formation layer and then the metal forming layer is 
possible, leading to more control of the contact formation process and improved conductivity of the conductor lines.

Next generation multicomponent inks (including surface modifying agents) have been developed to obtain improved fire-through contacts. These proprietary inks greatly improve the burn through and contact formation process. Fig. 5 depicts a $1 \mu \mathrm{m}$ deep, $70 \mu \mathrm{m}$ wide etch pattern obtained by inkjet printing an ink containing a proprietary etching agent on a $\mathrm{SiN}_{\mathrm{x}}$ coated Si substrate, followed by thermal processing at $750^{\circ} \mathrm{C}$ for $10 \mathrm{~min}$. Complete penetration of the $\mathrm{SiN}_{\mathrm{x}}$ layer was observed at temperatures as low as $500^{\circ} \mathrm{C}$.

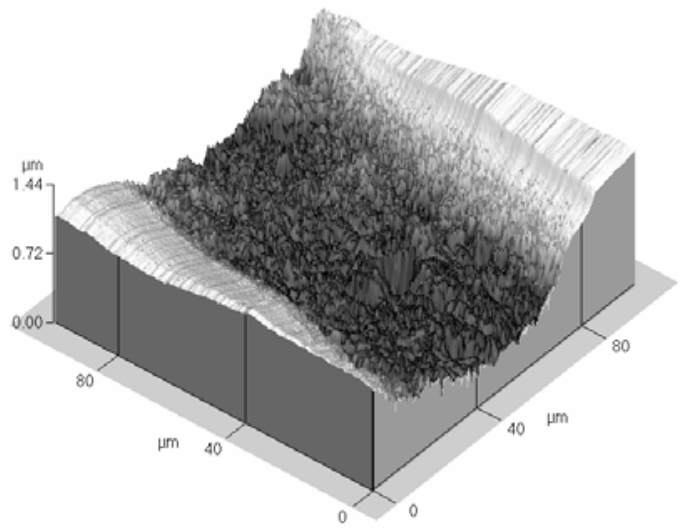

Fig. 5. AFM image of the $1 \mu \mathrm{m}$ deep, $70 \mu \mathrm{m}$ wide etch pattern produced by the inkjet-printed "fire-through" agent on an AR coated Si wafer

Experimental solar cells have now been fabricated using this process. These cells were formed by sequential printing of the etching agent layer followed by the deposition of the Ag lines from organometallic precursors as described above. Back contacts were screen-printed using Ferro's Al paste. However, annealing of the structure has proven to be more difficult than anticipated. Short (40 sec) anneals at $550^{\circ} \mathrm{C}$ in our lamp RTP furnace have yielded poor results due to non-uniform overheating and penetration of the contact layer too deep into the $\mathrm{Si}$ substrate. Short anneals in a conventional furnace have given better results, but the lack of good control of the time-at-temperature has limited these cells to modest efficiencies. Optimization of the annealing process is underway and should result in improved efficiencies.

\section{INKJET-PRINTED PEDOT-PSS CONTACT FOR ORGANIC SOLAR CELLS}

Organic solar cells and organic optoelectronics rely in many cases on thin films of PEDOT as an organic TCO. We report on an extension of the inkjet printing process to high performance PEDOT lines and films.

An aqueous suspension of PEDOT/PSS (Baytron $P$ HCV2) was obtained from Bayer. It was printed both asreceived and diluted with water or ethyl alcohol, and with additives such as dimethyl sulfoxide (DMSO) and surfactant (Surfynol 2502 from Air Products) in order to achieve highly conducting and smooth PEDOT-PSS films and patterns. Uniform PEDOT lines as narrow as $300 \mu \mathrm{m}$ were inkjet printed on glass substrates (Fig. 6).

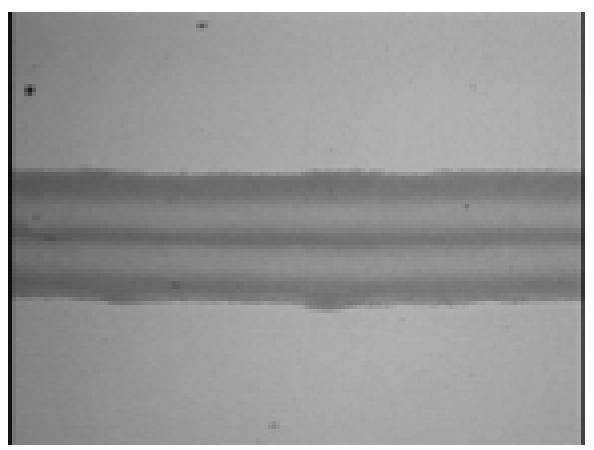

Fig. 6. 50x microscope image of the $300 \mu \mathrm{m}$ wide PEDOT line inkjet printed on ITO

Continuous films were produced by printing overlapping adjacent lines. The distance between the printed lines was varied for each ink composition in order to achieve smooth films. It was found that film roughness, thickness and conductivity were controlled by various parameters including type of solvent, dopant, substrate temperature and the settings of the inkjet. The smoothest films were achieved by printing at $50^{\circ} \mathrm{C}$. The inkjet-printed films were consistently more conducting than films spincoated from the same ink (Table 2).

Table 2 - Inkjet-printed versus spin-coated films

\begin{tabular}{|l|l|l|l|}
\hline Sample description & $\begin{array}{l}\text { Thickness } \\
(\mathrm{nm})\end{array}$ & $\begin{array}{l}\text { Rough- } \\
\text { ness } \\
(\mathrm{nm})\end{array}$ & $\begin{array}{l}\text { Conduc- } \\
\text { tivity } \\
(\text { S/cm })\end{array}$ \\
\hline Inkjet Printed PEDOT & 350 & 24 & 4.3 \\
\hline Spin-coated PEDOT & 160 & 2.5 & 3.1 \\
\hline $\begin{array}{l}\text { Inkjet - 1:1 } \\
\text { PEDOT/water }\end{array}$ & 150 & 24 & 4.7 \\
\hline $\begin{array}{l}\text { Spincoat - } 1: 1 \\
\text { PEDOT/water }\end{array}$ & 60 & 2.5 & 3.7 \\
\hline $\begin{array}{l}\text { Inkjet }-1: 1 \\
\text { PEDOT/water +5\% } \\
\text { DMSO }\end{array}$ & 300 & & 33 \\
\hline $\begin{array}{l}\text { Inkjet - 1:1 } \\
\text { PEDOT/water + 5\% } \\
\text { DMSO +1\% Surfynol }\end{array}$ & 300 & 40 & 51 \\
\hline $\begin{array}{l}\text { Inkjet - 1:1 } \\
\text { PEDOT/water + 1\% } \\
\text { DMSO +1\% Surfynol }\end{array}$ & 180 & 35 & 31 \\
\hline
\end{tabular}

The increased conductivity of the inkjet versus spincoated films is not entirely understood, but may be due to preferential polymer alignment or orientation that occurs with longer drying time. The best conductivity of $51 \mathrm{~S} / \mathrm{cm}$ was achieved by adding $5 \mathrm{wt} \%$ DMSO and 1\% Surfynol. The increase of conductivity with DMSO has been previously demonstrated for spin-coated films [4,5]. The 
surfactant Surfynol was added to the ink to improve the wetting properties of the polymer for smoother films. However, it not only produced visibly more uniform and smoother films, but it also increased the conductivity by a factor of about 1.5, which has not been observed before. Finally it was found that the value of the workfunction (by CPD) for the inkjet-printed polymer could be varied by as much as $0.5 \mathrm{~V}$ by various additives. This is instrumental for matching the workfunctions of the PEDOT-PSS layer with other layers in the device.

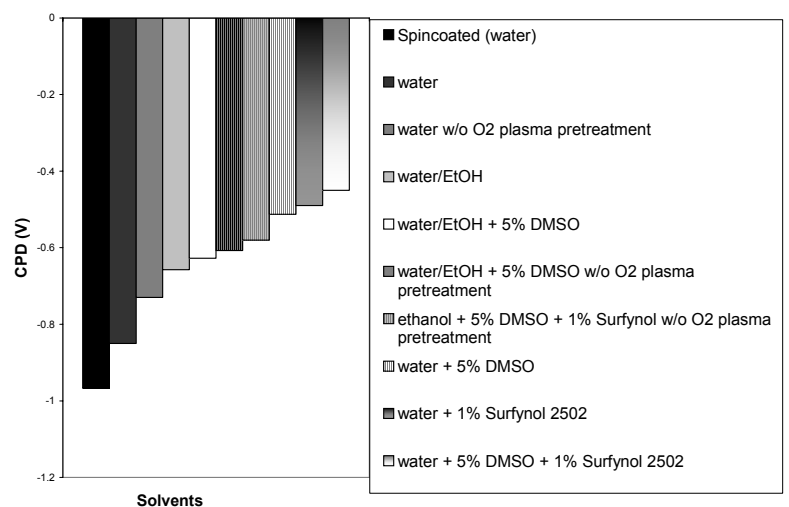

Fig. 7 - Contact Potential Difference (CPD) of PEDOT films printed under identical conditions with various solvents and substrate pretreatments.

\section{CONCLUSIONS}

In summary, we have developed atmospheric direct-write deposition of metals including $\mathrm{Ag}, \mathrm{Cu}$ and $\mathrm{Ni}$. Line widths, conductivities and thicknesses are comparable to or better than those produced by screen printing. We have shown how new inks can improve the contacting process for $\mathrm{Si}$ photovoltaics. We have demonstrated inkjet printed patterns of highly conductive PEDOT polymer for contacts in organic photovoltaic cells. Future work will focus on improved resolution, multicomponent/multifunctional inks for enhanced contacts and improved inks for better conductivities of $\mathrm{Cu}$ and $\mathrm{Ni}$ metallizations.

\section{REFERENCES}

[1] D. B. Wallace, W. R. Cox, and D. J. Hayes, DirectWirte Technologies for Rapid Prototyping Applications, $p$. 177.: Academic Press, 2002.

[2] C. J. C. T. Rivkin, A. Miedaner, J. Alleman, D. L. Schulz and D. S. Ginley, "Copper and silver inks for inkjet printing.," presented at 198 th International Symposium of the Electrochemical Sosciety, Phoenix, Arizona, 2000.
[3] C. C. T. Rivkin, A. Miedaner, J. Perkins, J. Alleman, and D. Ginley, "Direct Write Processing for Photovoltaic Cells," presented at IEEE 29th Photovoltaics Specialists Conference, New Orleans, Louisiana, 2002.

[4] S. K. M. Jonsson, J. Birgerson, X. Crispin, G. Greczynski, W. Osikowicz, A. W. D. van der Gon, W. R. Salaneck, and M. Fahlman, "The effects of solvents on the morphology and sheet resistance in poly $(3,4-$ ethylenedioxythiophene)-polystyrenesulfonic acid (PEDOT-PSS) films," Synthetic Metals, vol. 139, pp. 1-10, 2003.

[5] J. Y. Kim, J. H. Jung, D. E. Lee, and J. Joo, "Enhancement of electrical conductivity of poly(3,4ethylenedioxythiophene)/poly(4-styrenesulfonate) by a change of solvents," Synthetic Metals, vol. 126, pp. 311316, 2002 


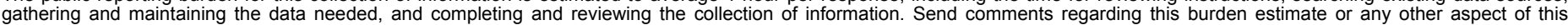

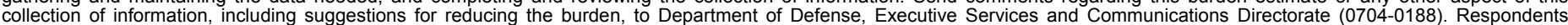

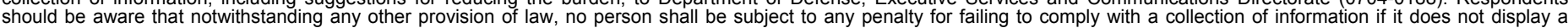

should be aware that notwithstanding

PLEASE DO NOT RETURN YOUR FORM TO THE ABOVE ORGANIZATION.

\section{REPORT DATE (DD-MM-YYYY) \\ February 2005 \\ 2. REPORT TYPE \\ Conference Paper}

4. TITLE AND SUBTITLE

Direct Write Contacts for Solar Cells
3. DATES COVERED (From - To)

3-7 January 2005

5a. CONTRACT NUMBER

DE-AC36-99-GO10337

5b. GRANT NUMBER

5c. PROGRAM ELEMENT NUMBER

5d. PROJECT NUMBER

NREL/CP-520-37524

5e. TASK NUMBER

PVA54201

5f. WORK UNIT NUMBER
7. PERFORMING ORGANIZATION NAME(S) AND ADDRESS(ES)

National Renewable Energy Laboratory

1617 Cole Blvd.

Golden, CO 80401-3393
8. PERFORMING ORGANIZATION REPORT NUMBER

NREL/CP-520-37524

9. SPONSORING/MONITORING AGENCY NAME(S) AND ADDRESS(ES)

10. SPONSOR/MONITOR'S ACRONYM(S) NREL

11. SPONSORING/MONITORING AGENCY REPORT NUMBER

12. DISTRIBUTION AVAILABILITY STATEMENT

National Technical Information Service

U.S. Department of Commerce

5285 Port Royal Road

Springfield, VA 22161

13. SUPPLEMENTARY NOTES

14. ABSTRACT (Maximum 200 Words)

$\mathrm{Ag}, \mathrm{Cu}$, and Ni metallizations were inkjet-printed with near-vacuum deposition quality. The approach developed can be easily extended to other conductors such as $\mathrm{Pt}, \mathrm{Pd}$, and $\mathrm{Au}$. Thick, highly conducting lines of $\mathrm{Ag}$ and $\mathrm{Cu}$ demonstrating good adhesion to glass, Si, and PCB have been printed at $100^{\circ}-200^{\circ} \mathrm{C}$ in air and $\mathrm{N}_{2}$, respectively. Ag grids were inkjet-printed on Si solar cells and fired through the silicon nitride antireflective layer at $850^{\circ} \mathrm{C}$ resulting in 8\%-efficient cells. Next-generation multicomponent inks (including etching agents) have also been developed with improved fire-through contacts leading to higher cell efficiencies. PEDOT-PSS polymer-based conductors were inkjet-printed with conductivity as good or better than that of spin-coated films.

15. SUBJECT TERMS

PV; direct wire contacts; solar cells; inkjet printing; multicomponent inks; polymer-based conductors; spin-coated films;

\begin{tabular}{|c|c|c|c|c|c|}
\hline 16. SECURITY & CLASSIFICATI & N OF: & 17. LIMITATION & 18. NUMBER & 19a. NAME OF RESPONSIBLE PERSON \\
\hline a. REPORT & b. ABSTRACT & c. THIS PAGE & UT ADSIRACI & & \\
\hline Unclassified & Unclassified & Unclassified & & & 19b. TELEPHONE NUMBER (Include area code) \\
\hline
\end{tabular}

